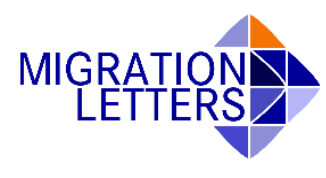

First Submitted: 11 December 2019 Accepted: 17 March 2020

DOI: https://doi.org/10.33182/ml.v17i2.927

\title{
VIEWPOINT
}

\section{Attracting High Skilled Individuals in the EU: The Finnish Experience}

\author{
Andrej Př́vara ${ }^{1}$, Eva Rievajová $^{2}$, Adina Barbulescu $^{3}$
}

\begin{abstract}
The ageing population, demographic change and a lack of skilled labour in the EU are increasingly provoking governments to apply direct measures to aggressively recruit economic migrants, particularly high skilled individuals (HSIS). As most countries in the EU face similar challenges, attracting HSIs from the third countries are predominantly vital. One of the EU-wide programs to attract skilled professionals is the Blue Card program, which was introduced in 2009 as part of the European Council Directive to focus on highly qualified employment, aimed at making Europe an appropriate host region for qualified workers from the non-EU countries. The EU Blue Card programme is adopted by 25 EU member states, apart from Ireland, Denmark and the United Kingdom. In this article, we discussed underlying features of the EU Blue Card program with a particular focus on the Finnish experience as one of the most successful the EU countries in attracting and retaining talent and HSIs.
\end{abstract}

Keywords: migration; high skilled individuals; HSIs; EU Blue Card program; Finland.

\section{Introduction}

Along with globalisation, the intensity of migration of people has grown, and economic activity has become progressively interrelated. Since society is becoming more and more knowledge-based, countries' demand for high skilled individuals (HISs) is increasing as they drive development and innovation, thus enabling nations to position themselves effectively in the competitive global environment. In light of population ageing and skill scarcities, attracting HSIs has become a vital task of all the countries (Filipec \& Vargová, 2019; Rehák, 2018; Ueki \& Guaita Martínez, 2019). Demographic change and a lack of skilled labour in the EU have been increasingly provoking governments into applying direct measures to recruit economic migrants, particularly HSIs, in an ardent manner. As most countries in the EU face similar challenges, HSIs from third countries are essential.

According to the European Commission Study on the movement of skilled labour 2018 (European Commission, 2018), high skill migration in the EU was growing faster than low skilled

\footnotetext{
${ }^{1}$ Andrej Př́vara, Faculty of National Economy, University of Economics in Bratislava, Bratislava, Slovak Republic. E-mail: andrej.privara@euba.sk.

${ }^{2}$ Eva Rievajová, Faculty of National Economy, University of Economics in Bratislava, Bratislava, Slovak Republic. E-mail: eva.rievajova@euba.sk.

${ }^{3}$ Adina Barbulescu, Department of Economics and Economic Modelling, Faculty of Economics and Business Administration, West University of Timisoara, Romania. E-mail: adina.barbulescu@e-uvt.ro.

Acknowledgement: This research was funded by Vega research project no. 1/0001/16: "Present and prospective changes in employment and related processes in the context of meeting the objectives of the European Employment Strategy" and VEGA research project no. 1/0287/19 "Integration of immigrants in EU countries from the point of view of migration policies".
} 


\section{Attracting High Skilled Individuals in the EU}

(Rehák, 2018; Pešek \& Kraft, 2019). This trend is accompanied by adverse labour market issues, such as disadvantages faced by immigrants, overeducation and qualification recognition across borders (Př́vara, 2019; Př́ivara et al., 2019; Sirkeci et al., 2018).

In view of the labour market challenges involving labour shortages, technological changes and demand for special skills, the EU has progressively viewed migration as a means to address these issues. According to the OECD, the EU hosts more migrant population than any other single OECD destination, with more than two million permanent-type migration flows to EU countries being reported in 2016. While one in three were new migrants to the EU, third-country nationals represented only about $4 \%$ of the whole EU working-age population between the ages of 15 and 64 (OECD, 2018a; Soon, 2018).

In 2016, employers in the EU reported the highest talent shortage since 2007. In Greece, around $59 \%$ of companies reported problems in filling skilled positions, followed by $49 \%$ in Germany, $45 \%$ in Poland and $40 \%$ in Austria. Clearly, the domestic labour force in some countries is not adequate to ensure the skill base. Countries are aiming to attract HSIs to fight growing skill shortages in the short and medium term (Danaj, Lazányi, \& Bilan, 2018; Martina Burmann, Maria Hofbauer Pérez, Vanessa Hoffmann, Carla Rhode and Sebastian Schworm1, 2018; Strielkowski, Rausser, Bilan, \& Tsevukh, 2018). In the current article, we explore underlying features of the EU Blue Card programme, with a focus on Finland's experience as one of the most successful EU countries in terms of attracting and maintaining talent and HSIs. In the following section, we outline the basic requirements of the EU Blue Card Programme and point out its strengths and weaknesses. In the subsequent section, we discuss the Finnish experience in developing such programmes for talent and HSIs. Finally, we conclude with some proposals for further avenues of research.

\section{The EU Blue Card Programme}

\section{Basic requirements}

One of the most widely adopted EU-wide initiatives to attract skilled professionals is the Blue Card programme. It was introduced in 2009 as part of the European Council Directive to focus on highly qualified employment, aimed at making Europe an attractive host region for qualified workers from non-EU countries. The EU Blue Card is acknowledged and applied by $25 \mathrm{EU}$ member states, with the exceptions amongst the union being Ireland, Denmark and the United Kingdom.

A principal requirement for applying to the Blue Card programme is a contract of employment of at least one year's duration. Other requirements vary depending on the destination country, particular, they include qualification certificates and verifiable work experience (Malec \& Királ'ová, 2018; Pisár, Huňady, \& Lapinová, 2018). Regarding which, Slovak requirements include professional qualifications from a reputable university and a salary of at least 1.5 times the average wage in the relevant field (International Organization for Migration, Migration Information Centre, 2019). Germany's EU Blue Card eligibility criteria, in addition to a one-year contract, require at least five years experience in a relevant field and an annual gross salary of at least EUR 53,000. There is a lower threshold of at least EUR 41,808 for medical workers, engineers, technicians, mathematicians and natural scientists (Visaguide, 2020). The shortest validity period of 12 months is in Bulgaria, Lithuania, Portugal, Spain, Cyprus and Malta, whilst in Latvia is 60 months. The member states issuing relatively high shares of EU Blue Cards vary in their validity periods from 24 to 48 months. The processing fees differ across the member states from 50 Euros in Cyprus to 881 Euros in the Netherlands (European Commission, 2020). 


\section{Attractiveness of the EU Blue Card Programme: Strengths and weaknesses}

When analyzing the attractiveness of the EU Blue card programme, it should be noted that there are important benefits for professionals from third countries. First, in accordance with the European Directive (Euro Commission, 2009), EU Blue Card holders must be treated equitably to the national population from the point of social legislation and employment law. Second, professionals from those countries can enjoy some rights once the residence permit has been approved in terms of free movement within the EU, permanent residence status, employment and family reunification. As far as family reunification is concerned, the directive allows close family members to live and work in the member state where the EU Blue Card holder is registered. Residence permits for family members must be issued at least six months after the application for family reunification has been submitted. However, concerning employment, EU Blue Card holders are not granted the right to be self-employed during the first two years of residence. If there is a change in employment, the national authorities will need to issue official permission throughout this term. After at least 18 months of working and living in a member state, EU Blue Card holders and their families are granted the right to move to another member state for working purposes in cases where the criteria for the qualified profession in the second member are satisfied (Boxall et al., 2019; Haindorfer, 2020; Verwiebe et al., 2017; Yu, 2019). A permanent residence permit can be acquired after five years of stable residence under EU Blue Card status. The holder must have been living and working in the member state in which the permanent residency application is submitted two years ahead of the term to obtain permanent residence status (OECD, 2018a).

It should be noted that the EU Blue Card programme is usually thwart with weighty bureaucracy, thus leaving individual immigrants and potential employers with long waits before the situation is remedied. Furthermore, there is also misinterpretation by some member state governments as to who is wanted in their labour markets. Only a particular group of people is targeted as the definition of "highly qualified" worker suggests in the Blue Card Directive. Criteria do not only cover the qualifications but also professional experience and a minimum wage requirement that differs between member states. Rather than welcoming the recent immigrants, many member states' positions appear to have been prudent and distrustful (Boucher, 2019).

The intra-mobility component of the EU Blue Card programme was initially very important. The member states agreed on the option to move between the EU countries, i.e. after an 18-month period the cardholder would be eligible to move to another member state. However, intra-EU mobility is often impeded, because the admission conditions have to be complied with for the second member state, which can often include a restrictive national quota. The EU is not perceived as one European labor market. However, the perception of such a market could be accomplished in the future and for this, the promotion of intra-EU mobility could play a significant role.

The Blue Card Directive has set minimum standards specifying a common floor, but not a common ceiling. It should be noted that there are no common rules and the level of rights are not the same for the targeted HSIs, there many loopholes in the Directive for member states to introduce exceptions, as reflected in the administration of the Blue Card Directive in the national systems. That is, there is inconsistency in the national rules, which makes intra EU mobility difficult for many cardholders. In this regard, the question of value added of the Blue Card Programme arises. There has been substantial improvement in legal situation of third-country nationals in the EU due to the introduction of the Family Reunification and the Long-Term Residents' Directives. However, any other value added by the Blue Card Directive is difficult to identify. In fact, the directive is not 


\section{Attracting High Skilled Individuals in the EU}

the solution of present competition among national schemes in place. EU member states laso have bilateral conventions with selected third countries, which contributes to a multi-layered system. Furthermore, the validity of the Blue Cards issued by the member states diverges considerably, from three months to four years. This adds further to the incompatibility concerns across the Union.

According to the Blue Card Directive, HSIs are entitled to a greater set of rights than other third-country workers, which raises questions around discrimination. It is not clear how privileged treatment based on higher education, professional skills and wage levels compies with the general principle of non-discrimination. The underlying reason for diversity lies in the sectoral approach followed by the EU. It is also become clear that no agreement could be achieved for a horizontal approach in EU labour migration that is relevant to all third-country nationals. The equal treatment for Blue Card holders is left to the discretion of member states issuing them in specific sectors. Finally, provision prescribing equal treatment regarding tax benefits and social assistance has been abandoned by Hungary, Germany and the Czech Republic.

\section{Finland's experience in developing national policies for HSIs and talent}

In addition to supra-national policies, member states' governments have introduced powerful direct national measures to engage HSIs. Since the EU Blue Card programme forms only a part of high skilled migration to the EU, this gives the opportunity to member states to attract additional such people and to distinguish themselves within the Community as being an attractive destination country. In the sections below, we take a closer look at Finland's case, which has implemented variations on a points-system to manage migration flows. In Table 1 below, we lay out thr policy measures of Finland regarding the attraction of HSIs.

Table 1: HIS and talent attraction programmes in Finland

\begin{tabular}{|c|c|}
\hline Policy measures & Targets \\
\hline $\begin{array}{l}\text { Introduction of Talent Boost Action Plan } 2017 \text { - } \\
2019\end{array}$ & $\begin{array}{l}\text { Develop Finland's country brand and the country's } \\
\text { ability to attract growth entrepreneurs and talent } \\
\text { groups. Stimulating the recognition of Finland as } \\
\text { well as Finnish cities and employers among } \\
\text { international talent }\end{array}$ \\
\hline $\begin{array}{l}\text { - Government Integration Programme, } 2016 \text { - 2019; } \\
\text { - Action Plan on Integration }\end{array}$ & $\begin{array}{l}\text { Develop positive attitudes, non-discrimination and } \\
\text { diversity management in cooperation with labour } \\
\text { market organisations }\end{array}$ \\
\hline National working life strategy, Working Life 2020 & $\begin{array}{l}\text { Strengthen practices based on trust, mutual } \\
\text { appreciation, openness and reciprocity in Finnish } \\
\text { workplaces }\end{array}$ \\
\hline Development of a system of ambassadors & Spread information about Finland \\
\hline $\begin{array}{l}\text { Business Finland Programme, January 1, } 2018 \text { and } \\
\text { merged two of the main Team Finland actors: } \\
\text { Finpro and Tekes }\end{array}$ & $\begin{array}{l}\text { Support route to international networking for } \\
\text { Finnish companies and attracting international } \\
\text { investments to Finland, and through them talent and } \\
\text { competence }\end{array}$ \\
\hline
\end{tabular}


Development of services

Future Migration 2020 Strategy
Settlement and integration, tax-related advice, offering services in English and in the other main languages spoken by migrant workers, and provision of international schools

To create an immigration policy that supports the building of an unprejudiced, safe and pluralistic Finland, one which also enhances Finland's international competitiveness

\section{Strong cooperation with NGOs}

Assist interaction between population groups

Source: Developed by the authors based on the Ministry of the Interior (2018), Prime Minister's Office (2017), European Web Site on Integration - European Commission (European Commission, 2013)

Finland, as with other EU countries, is characterised by an ageing population and the necessity for HSIs there will increase in the future. The barrier most often encountered by foreigners is speaking Finland's official languages (United Nations, Department of Economic and Social Affairs, \& Population Division, 2020). However, according to the Global Talent Competitiveness Index 2019, Finland is among leaders of the EU member states, being ranked $4^{\text {th }}$ in terms of ability to attract and retain talent (Lanvin \& Monteiro, 2019) (Figure 1, 2).

Figure 1: Ability to attract talent among EU member states

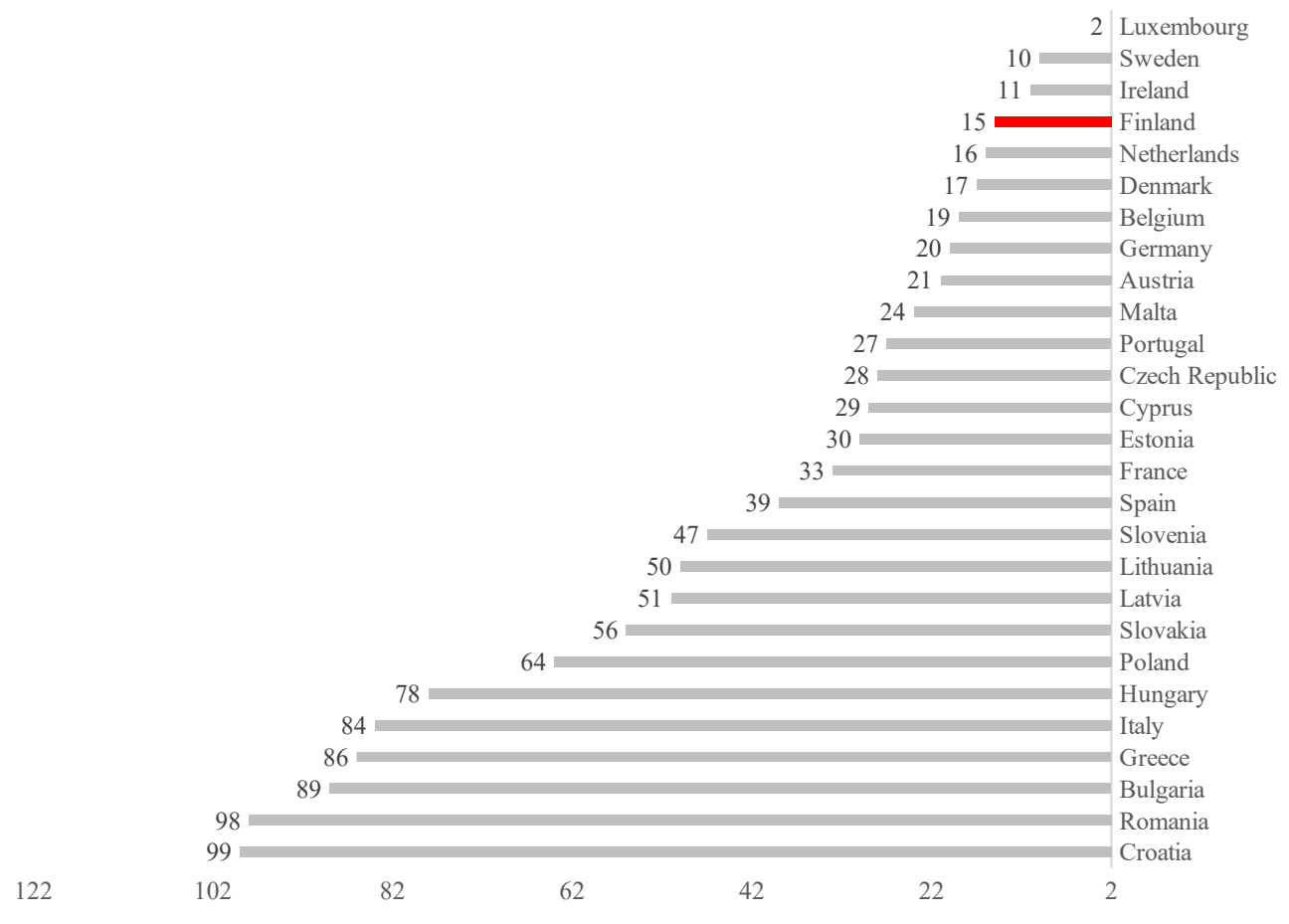

Source: Author, based on Global Talent Index 2019 (Lanvin \& Monteiro, 2019)

Finnish law does not distinguish between a skilled or highly skilled migrants, and an exact definition of HSIs does not exist. Regarding skilled and HSIs, the law refers to those individuals who work in expert roles in middle or top management of a company or professionals with special 


\section{Attracting High Skilled Individuals in the EU}

expertise (García, 2013). Finland's biggest weakness as a country brand to attract talent and high skilled people is its location, climate and being perceived as "not-international". The impression of being remote and depictions of vast empty spaces are not necessarily appealing. Images used for the promotion of tourism are not necessarily ideal for attracting talent and HSIs (OECD, 2018b). This is clear in the Figure 2, which shows that Finland comes among the top four of least successful EU countries when it comes to retaining talent.

Figure 2: Ability to retain talent among EU member states

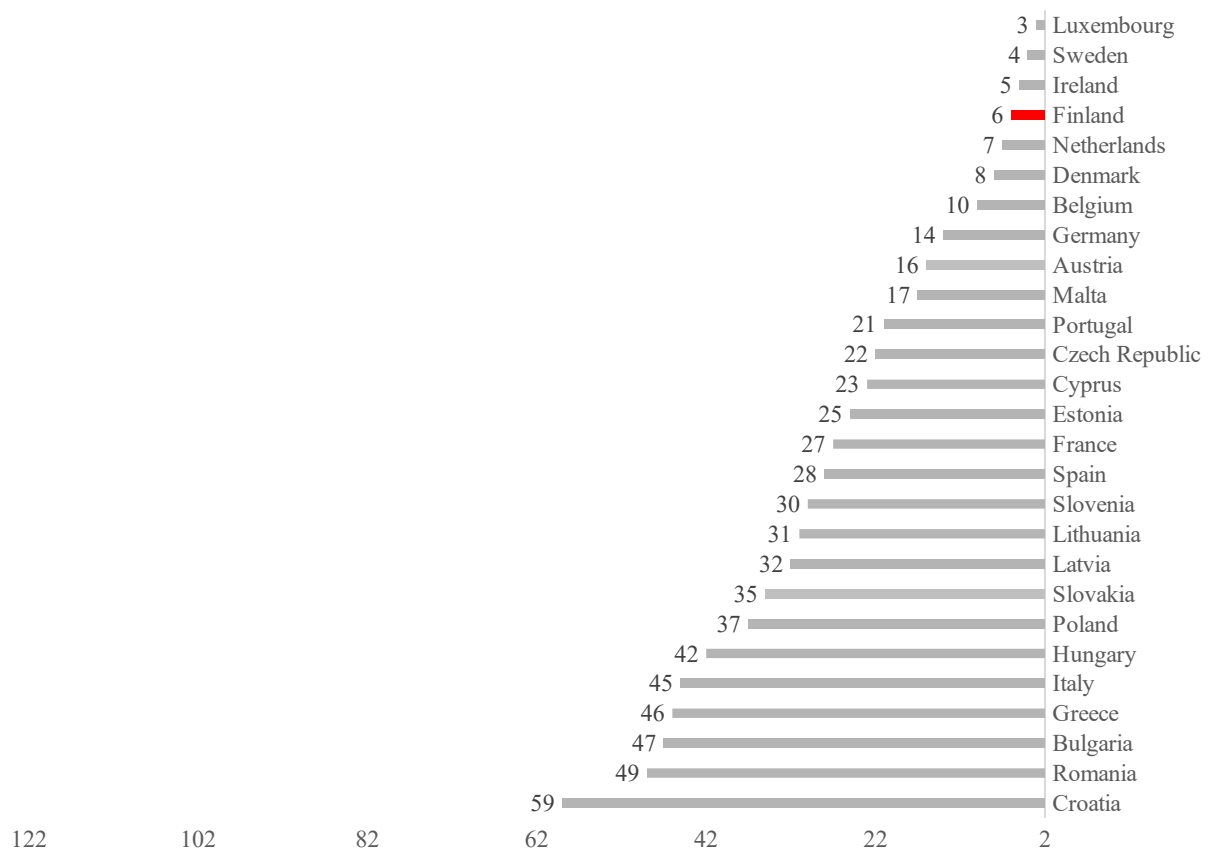

Source: Author, based on the Global Talent Index 2019 (Lanvin \& Monteiro, 2019)

The benefits of Finland in the competition for international talent comprise a safe and stable society, well-functioning public services, including an internationally recognised excellent education system, abundant cultural offerings, generous social welfare programmes, highly effective healthcare and universal children's day care. Among other identified pull factors for Finland are its well ordered society, high levels of equality, clean living conditions, nearness to nature and procative civic culture (Kushnirovich, 2019).

\section{Conclusions and discussion}

In our research, we considered the strengths and weaknesses of the EU Blue Card programme. Among the attractive benefits of the programme is equal treatment alongside the national population in terms of social legislation and employment law as well as the right to free movement within the EU, once the residence permit has been approved.

However, there are some issues regarding the EU Blue Programme implementation. In particular, the EU Blue Card program ignored the interests of the individual immigrants and businesses who still may have to face a slow and difficult bureaucracy. The requirements vary 
considerably between member states that can be seen as an outcome of the distrustful positions adopted by member states whilst the Blue Card Directive was being drawn up.

The intra-mobility component of the EU Blue Card programme was initially considered to be important; however, it is not quite clear whether this feature attracts HSIs. In fact, in order to become mobile within the EU, the Blue Card holder needs to be "immobile" for some period. Intra-EU mobility can be easily impeded as the admission conditions have to be complied with other member states, which may also apply national quota.

On the assumption that the Blue Card scheme is continued, the aim of the programme should be emphasised again: the development of a flexible admission system that lets businesses and entities recruit workers in accordance with their needs. This flexible admission system may, however, not be applied at the cost of the rights of the individual, as an HSI system cannot place economic considerations above the rights and needs of migrants. A Blue Card Directive that is framed in accordance with a rights based approach protecting the interests of those persons to whom the measure applies, would increase the attractiveness of the Blue Card.

Our research of the Finland experience in attracting talents and HSIs has shown that programs aiming to attract talents appear to be effective, often combined by well-functioning public services, including internationally recognized education systems, other services such as social welfare, healthcare and children's day care.

In this article, we have focused on the EU Blue Card programme and the Finnish experience in attracting talent. However, a further area of research lies in exploring the effects of EU efforts aimed at attracting students, particularly those pursuing higher level degrees. In accordance with the aims of the European Migration Network (European Migration Network, 2018) attracting students and highly skilled workers remains essential for the EU community. The community has sought to create a favourable and attractive environment for workers by reviewing the EU Blue Card and adopting a revamped Students and Researchers Directive (European Commission, 2019).

In recent years, the EU and its member states have been working on several broad strategies to boost the attractiveness of Europe's higher education system. The most outstanding example at EU level, is the new students and researchers directive adopted in 2016 (Directive (EU) 2016/801) (European Commission, 2016), which particularly pursues developing and harmonising minimum legal standards for hosting and retaining international students. Some member states at the national level have developed new national strategies aimed at attracting students and many universities have improved their efforts to grow their international student cohort. Many governments have concluded bilateral and multilateral agreements with third countries, in order to enable the admission of the latter's national students to the EU. Thus, future research can be devoted to exploring the quantitative and qualitative effects of the Directive.

It should also be mentioned that the workforce composition in multinational companies is a vital factor of HSI migration, however, is often underappreciated in the migration studies (Kerr, Kerr, \& Lincoln, 2014). Many multinational companies require their executives to work abroad as a prerequisite for senior leadership positions. International companies, like General Electric, Siemens, IBM, Henkel and Lenovo typically have at least half of their employees employed outside of the country where their headquarters are located. Outstanding firms with immigrant chief executive officers are not limited to high-tech, such as Microsoft and Google, for they also include 


\section{Attracting High Skilled Individuals in the EU}

many traditional firms, such as Clorox Alcoa, Dow Chemical, McDonalds, Pepsi and Coca-Cola. Thus, the abovementioned factors affecting HSI destination decisions should be also investigated.

Additional important area warranting research pertains to the offshoring by non-English speaking countries their higher education abroad. Countries with established HSI programmes, in particular, Canada, the US, Australia have equally decentralised labor markets that are prone to promote open door policies. In contrast, new immigration countries without any clear HSI policies are characterised by relatively unorganised employers focusing on low-skilled workers, and lack of involvement by the state (Almosova, 2014; Cerna, 2014). The interest of non-English speaking countries, such as France and Germany, in offshoring their higher education abroad, often via the implementation of programmes in English, but with the strict goal of promoting their national languages, is important for attracting HSI in the future (Levatino, 2015).

\section{References}

Akanle, O. (2018). International migration narratives: Systemic global politics, irregular and return migrations. International Sociology, 33(2), 161-170. https://doi.org/10.1177/0268580918757105

Almosova, A. (2014). Labor market institutions and the effect of immigration on national employment. Business and Economic Horizons, 9(4), 53-74. https://doi.org/10.15208/beh.2013.22

Boucher, A. K. (2019). How 'skill' definition affects the diversity of skilled immigration policies. Journal of Ethnic and Migration Studies, 1-18. https://doi.org/10.1080/1369183X.2018.1561063

Boxall, P., Huo, M.-L., \& Winterton, J. (2019). How do workers benefit from skill utilisation and how can these benefits be enhanced? Journal of Industrial Relations, 61(5), 704-725. https://doi.org/10.1177/0022185618819169

Cerna, L. (2014). Attracting High-Skilled Immigrants: Policies in Comparative Perspective. International Migration, 52(3), 69-84. https://doi.org/10.1111/imig.12158

Danaj, A., Lazányi, K., \& Bilan, Y. (2018). Perceptions and Implications of Immigration in France - Economic, Social, Political and Cultural Perspectives. Economics \& Sociology, 11(3), 226-247. https://doi.org/10.14254/2071789X.2018/11-3/14

Euro Commission. (2009). Council Directive 2009/50/EC. Retrieved from EuroLex website: https://eurlex.europa.eu/legal-content/EN/TXT/?uri=celex:32009L0050

European Commission. (2013). European Web Site on Integration-European Commission. Retrieved February 2, 2020, from European Commission website: https:/ec.europa.eu/migrant-integration/librarydoc/finland-future-ofmigration-2020-strategy

European Commission. (2016). Directive (EU) 2016/801 of the European Parliament and of the Council. Retrieved February 2, 2020, from EuroLex website: https://eur-lex.europa.eu/eli/dir/2016/801/oj

European Commission. (2018). Study on the movement of skilled labour [Final Report]. Retrieved from European Commission website: https://ec.europa.eu/social/BlobServlet?docId=20453\&langId=mt

European Commission. (2020). EU Immigration Portal. Retrieved from European Commission website: https://ec.europa.eu/immigration/blue-card/

European Migration Network. (2018). Understanding Migration in the European Union: Insights from the European Migration Network 2008-2018. Retrieved from European Migration Network website: http://emn.ie/cat_publication_detail.jsp?clog=1\&itemID $=3144 \& \mathrm{t}=6$

Filipec, O., \& Vargová, N. (2019). Perception of Migration from Non-Eu Countries in Slovakia: The Case of Nitra Region. European Journal of Transformation Studies, 7(2), 165-175.

García, F. (2013). Integration of highly skilled third country nationals in Europe: A new proposal for circular talent management. Retrieved from University Institute of Studies on Migration, Comillas Pontifical University website: http://www.mitramiss.gob.es/oberaxe/ficheros/ejes/cooperacion/Integration_highly_skilled_third_country_nationals in_Europe.pdf

Haindorfer, R. (2020). Impacts of negative labor market experiences on the life satisfaction of European East-West mobile workers: Cross-border commuters from the Czech Republic, Slovakia and Hungary in Austria. Journal of Industrial Relations, https://doi.org/10.1177/0022185619897087 
International Organization for Migration, Migration Information Centre. (2019). Temporary Residence-EU Blue Card. Retrieved from MicIom website: https://www.mic.iom.sk/en/residence/temporary-residence/236-modra-karta-eu2.html

Kerr, S. P., Kerr, W., \& Lincoln, W. (2014). Firms and the Economics of Skilled Immigration (No. w20069; p. w20069). https://doi.org/10.3386/w20069

Kushnirovich, N. (2019). Labor Market Integration of Skilled Immigrants. Journal of International Migration and Integration, 20(4), 1055-1070. https://doi.org/10.1007/s12134-018-00648-7

Lanvin, B., \& Monteiro, F. (2019). The Global Talent Competitiveness Index. Retrieved from INSEAD website: https://gtcistudy.com/wp-content/uploads/2019/01/GTCI-2019-Report.pdf

Levatino, A. (2015). Transnational higher education and skilled migration: Evidence from Australia. International Journal of Educational Development, 40, 106-116. https://doi.org/10.1016/j.ijedudev.2014.11.009

Malec, L., \& Királová, A. (2018). Evaluating Competencies of Graduates in Tourism as a Prerequisite for Future Employability. Prague Economic Papers, 27(2), 196-214. https://doi.org/10.18267/j.pep.651

Martina Burmann, Maria Hofbauer Pérez, Vanessa Hoffmann, Carla Rhode and Sebastian Schworm1. (2018). Highly Skilled Labour Migration in Europe [DICE report]. Retrieved from Leibniz Institute for Economic Research at the University of Munich website: https://www.ifo.de/DocDL/dice-report-2018-1-burmann-et-al.pdf

Ministry of the Interior. (2018). Work in Finland-Government Migration Policy Programme to Strengthen Labour Migration (No. 5/2018). Retrieved from Ministry of the Interior website: http://julkaisut.valtioneuvosto.fi/bitstream/ handle/10024/160518/05\%202018\%20SM\%20Work\%20in\%20Finland.pdf

OECD. (2018a). OECD economic surveys: European Union 2018. Paris: OECD Publishing.

OECD. (2018b). Working Together: Skills and Labour Market Integration of Immigrants and their Children in Finland. https://doi.org/10.1787/9789264305250-en

Pešek, O., \& Kraft, S. (2019). Spatial mobility and current travel behaviour in the metropolitan hinterland. Geografický Časopis - Geographical Journal, 71(3). https://doi.org/10.31577/geogrcas.2019.71.3.14

Pisár, P., Huňady, J., \& Lapinová, E. (2018). Work Flexibility in Developed Countries: Economic Context and Policy Implications. Prague Economic Papers, 27(6), 684-703. https://doi.org/10.18267/j.pep.688

Prime Minister's Office. (2017). Finland, a land of solutions Mid-term review: Government Action Plan2017-2019 (No. 7/2017). Retrieved from Prime Minister's Office website: https://valtioneuvosto.fi/documents/10184/321857/ Government+action+plan+28092017+en.pdf

Privara, A., Rievajová, E., \& Yüceşahin, M. M. (2019). Labour Market Disadvantages Faced by Migrant Workers from Czech Republic, Hungary, and Slovakia in Britain. Migration Letters, 16(4), 585-594. https://doi.org/10.33182/ml.v16i4.720

Př́vara, A. (2019). Citizenship-for-Sale Schemes in Bulgaria, Cyprus, and Malta. Migration Letters, 16(2), 245-254. https://doi.org/10.33182//ml.v16i2.735

Rehák, R. (2018). Environmental solutions in practice. Ekonomika cestovného ruchu a podnikanie, 10(1), 64-76.

Rehák, R. (2018). Electromobility in European Union. Ekonomika cestovného ruchu a podnikanie, 10(1), 53-63.

Sirkeci, I., Acik, N., Saunders, B., \& Přívara, A. (2018). Barriers for highly qualified A8 immigrants in the UK labour market. Work, employment and society, 32(5), 906-924. https://doi.org/10.1177/0950017017726912

Soon, J.-J. (2018). Effects of EU Expansion on Migrants Employment and Income: A Natural Experiment. Prague Economic Papers, 27(1), 113-128. https://doi.org/10.18267/j.pep.648

Ueki, Y., \& Guaita Martínez, J. M. (2019). The impact of engineers' skills and problem-solving abilities on process innovation. Economic Research-Ekonomska Istraživanja, 1-20. https://doi.org/10.1080/1331677X.2019.1596826

United Nations, Department of Economic and Social Affairs, \& Population Division. (2020). World population ageing, 2019 highlights.

Verwiebe, R., Reinprecht, C., Haindorfer, R., \& Wiesboeck, L. (2017). How to Succeed in a Transnational Labor Market: Job Search and Wages among Hungarian, Slovak, and Czech Commuters in Austria. International Migration Review, 51(1), 251-286. https://doi.org/10.1111/imre.12193

Visaguide. (2020). EU Blue Card Germany. Retrieved from Visaguide website: https://visaguide.world/europe/eu-bluecard/germany/

Yu, K.-H. (2019). Negotiating 'otherness' as skilled migrants. Journal of Industrial Relations, 61(2), 198-224. https://doi.org/10.1177/0022185618802607 
OVEREDUCATED AND OVER HERE

SKILLED EU MIGRANTS IN BRITAIN Having spent approximately half my life away from my home country. it is perhaps not sunprising that l chose to examine the ives of others. who made sinicar decisions. A culture of migration runs in the family. Whether these were academics from Lend on or labout shares. Whether these were acadernics from London or labouters from Lahore, my conversations with them made me refiecton and question our life choices and experiences. Why hod we decided to leave one country and move to another? Was there some thing a move?

Bradley Saunders received his PhD from Loughborough University and currently works at Prince Mohammad Bin Fahd University, KSA. He previously worked Regent's University London. DrSaunder' academic interests include internatione manogement, gobalisalion, overeducation EU migrant workers, self-initiated expattiates, job transitions, an cormorate expatriation

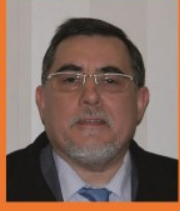
job transitions, an,
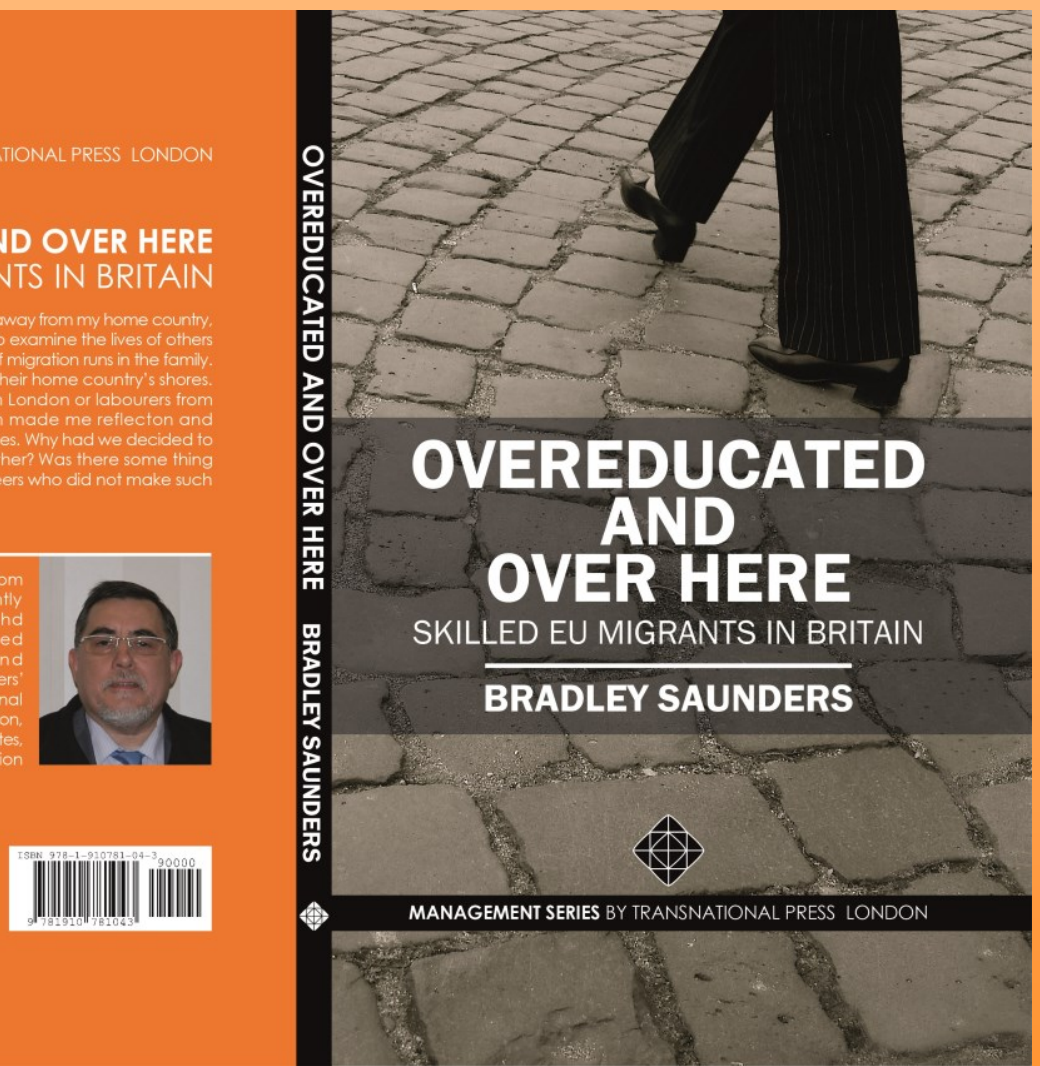

Please visit

www.tplondon.com

...fostering research, widening reach... 